\title{
Open Lung Biopsy
}

National Cancer Institute

\section{Source}

National Cancer Institute. Open Lung Biopsy. NCI Thesaurus. Code C51923.

Removal of tissue from the lung, for microscopic examination, obtained during an open surgical procedure. 